\title{
Effect of Electronic waste on Environmental \& Human health- A Review
}

\author{
Mahipal Singh Sankhla ${ }^{1}$, Mayuri kumari ${ }^{1}$, Manisha Nandan ${ }^{1}$, Shriyash Mohril ${ }^{2}$, \\ Gaurav Pratap Singh ${ }^{2}$, Bhaskar Chaturvedi ${ }^{3}$, Dr. Rajeev Kumar ${ }^{4}$. \\ ${ }^{I}$ Students of M.Sc. Forensic Science, Division of Forensic Science, School of Basic and Applied Sciences. \\ ${ }^{2}$ Students of Electronics and Communication Engineering, School of Electrical \& Electronics and \\ Communication Engineering. \\ ${ }^{3}$ Student of Mechanical Engineering, School of Mechanical Engineering, \\ ${ }^{4}$ Assistant Professor, Division of Forensic Science, School of Basic and Applied Sciences. Galgotias University, \\ Greater Noida. Uttar Pradesh, India
}

\begin{abstract}
Waste of electrical and electronic apparatuses generated in huge amount surround the earth today, and has become a global environmental issue. Electronic waste is a common, informal name for electronic products approaching the end of their useful life. The current and the future production of e-waste, the potential environmental problems associated with their disposal and management practices are discussed whereas the existing e-waste management. E-wastes are considered dangerous, as certain components of some electronic products contain materials that are harmful, depending on their condition and density. The harmful content of these materials pose a threat to human health and environment. Its toxic emissions mixed with virgin soil and air and causing harmful effects to the entire biota either directly or indirectly. Direct impacts include release of acids, toxic compounds including heavy metals, carcinogenic chemicals and indirect effects such as bio magnification of heavy metals. Discarded computers, televisions. DVD. stereos, copiers, fax machines, electric lamps, cell phones, audio equipment and batteries if improperly disposed can leach lead and other substances into soil and groundwater.
\end{abstract}

Keywords: Electrical waste, environment, soil, emission.

\section{Introduction}

The electronic industry is the world's largest and fastest growing manufacturing industry [1,2]. Electronic waste is informally known as e-waste for the electronic products nearing the end of their useful life. This is largely due to increasing market penetration of products in developing countries, development of a replacement market in developed countries and a generally high product obsolescence rate, together with a decrease in prices and the growth in internet use. Electrical and Electronic waste (e-waste) is defined as any discarded, obsolete, or broken electrical or electronic devices. As per current estimates, e-waste is growing almost three times the rate of municipal Solid Waste globally [3]. E-waste, being one of the largest sources of heavy metals and organic pollutants in municipal waste and the fastest growing waste stream, has become a serious problem in China and other Asian developing nations [4]. These countries not only generate tremendous amounts of domestic e-waste due to their fast consumption rates of electrical and electronic (EE) products, but also receive enormous quantities of used information technology (IT) devices from overseas [5]. In China, ewaste is largely recycled by the informal sector, where numerous waste recycle workers are hired at extremely low wages applying crude and pollutive erecycling methods for separation of reusable components and quick recovery of contained metals. These backyard practices often take place under the waste. E-waste from developed countries find an easy way into developing countries in the name of free trade [6]. India is a developing county, from the last decades increase in population \& change of lifestyle, the demand of using electronic products is increased. In India e-waste generation is growing at $15 \%$ \& is expected to cross 8000000 tones per year in 2012.A Central pollution control board (CPCB) report said 65 cities in India generate more than $60-70 \%$ of the total e-waste, which comes from 10 states, that's are followed by Maharashtra, Tamilnadu, Andhra Pradesh, Uttar Pradesh, West Bengal, Delhi, Karnataka, Gujarat, Madhya Pradesh and Punjab in the list of e-waste generating states in India [7,8].Most erecyclers were exporting the toxic materials such as leaded glass, circuit boards, and mercury lamps usually to China, Africa and India [8,9].It is an emerging problem as well as a business opportunity of increasing significance, given the volumes of e-waste being generated and the content of both toxic and valuable materials in them. The fraction including iron, copper, aluminum, gold and other metals in e-waste is over $60 \%$, while plastic account for about $30 \%$ and the hazardous pollutants comprise only about $2.70 \%$ [10].Today, electrical and electronic waste (hereafter referred to as e-waste) is the fastest growing waste stream (about 4 per cent growth a year). About 40 million tones of e-waste is created each year [11]. In the last years, there is an increasing acknowledgment of our impact on the environment due to our 
lifestyle, while the need to adopt a more sustainable approach concerning our consumption habits emerges as of particular significance. This trend regards industrial sectors affecting the consumption habits and, especially, electronic industry where the short life cycles and the rapidly developing technology have led to increased ewaste volumes. The majority of e-waste elements are led to landfills. However, their partial recyclability, due to their material composition along with the unavoidable restrictions in landfills, has led to the development of retrieval techniques for their recycling and re-use, highlighting the significance of e-waste recycling, not only from a waste management aspect but also from a valuable materials' retrieval aspect [12]. According to the Basel Convention, wastes are substances or objects, which are disposed of or are intended to be disposed of, or are required to be disposed of by the provisions of national laws [13].

\section{E-waste in India}

E-waste in India: research unit (LARRDIS), Rajya Sabha Secretariat, New Delhi June 2011: This publication is the next in the series of 'Occasional Paper' being brought out by the Rajya Sabha secretariat on topical issues, from time to time, for the benefit of Members of Parliament. The augmentation of human capabilities due to industrial revolution is well documented. The revolutionary changes experienced in societies across the world due to the application of electronics are far more deep and widespread than the impact of industrial revolution. The electronics age made unprecedented impact on human society and spectacularly enhanced our connectivity across the globe. The widespread use of electronic items has made communication easier, boosted business activities and created employment opportunities. However, along with the benefits, it has brought into focus many challenges, like the rising problem of e waste that have to be boldly dealt with by society. In the current scenario, it is always possible that human health and environment would be drastically endangered if concerted legislations and actions were not taken efficient management and disposal of e-waste.

The main sources of electronic waste in India are:

A. Solder in printed circuit, glass panels \& gaskets in computer monitor

B. Chip resistors \& Semiconductors

C. Refrigerators \& Batteries

D. Mobiles

E. Microwave \& Air Conditioners etc.

The story of current Indian e-waste management is different from the worldwide. Practices E-waste is a serious issue because of the informal recycling activities. Therefore, quantification of e-waste in India is very difficult and, there is no mechanism and policy to check the flow of e-waste in the system. In case of PCs, $22 \%$ of the e-waste is generated by households and it is the business sector which accounts for the $78 \%$ the e-waste, because $83 \%$ of household customers are first time buyers. So business sector is mainly responsible for the waste generation. In addition to this, about 1050 tones per year of computer waste comes from retailers and manufacturers. This is important to note that in spite of global agreements, e-waste from developed nations is imported to developing nations like India [14].IT and telecom are two fastest growing industries in the country. India, by 2011, has achieved a PC penetration of 95 per 1000 from the 14 per 1000 in 2008. At present, India has 95 million one of the most threatening substances is lead, of which only 5 percent is recycled in India [15].

\section{Status of E-waste in Delhi}

The main factors that contribute to the thriving e-waste recycling business in Delhi - its status as the capital and hence its connectivity to all parts of the country; the many satellite towns around it, where several hundreds of small units treat e-waste; and the availability of cheap migrant labor. Nearly $70 \%$ of electronic waste collected at recycling units in New Delhi was actually exported or dumped by the developed nations. The amount of e-waste generated is about 12,000 tones per annum. Though not the leading generator, Delhi is the leading e-waste processor in the country. According to the study conducted by the GTZ in 2007, there were about 25,000workers refurbishing 10,000-20,000 tones of e-waste annually. The work takes place in small illegal units where neither regulations nor environment or health safeguards are in place. Due to lack of facility for proper storage and disposal of such waste, it frequently results in mishaps $[\mathbf{1 6 , 1 7 ]}$.

\section{Status of E-waste in Mumbai}

Mumbai, the financial nerve center of India and which is India's largest port city where the Information Technology industry has originated contributes20270.59tonnes of e-waste per annum. In India, Mumbai ranks first among top ten cities generating waste electrical and electronic equipment's (WEEE).The Mumbai-Pune industrial belt is one of the electronic items manufacturing hubs of the country. As a result, Mumbai is not only the port of import for new and used electronics; it is also home to a large user and manufacturer base, both generating large volumes of e-waste [18]. 


\section{Status of E-waste in Bangalore}

Bangalore, the Silicon capital of India, e-waste recycling is a multi-crore market where e-waste is received in Goripalyam and Nayandahalli. The e-waste scrap dealers send the segregated and dismantled ewaste parts to Delhi and Mumbai every alternative day. The e-waste recyclers earn around 2-3 lakhs a month from selling the dismantled e-waste to Delhi. There are nearly 50 registered recycling centers in Karnataka like M/s. E-Wardd \& Co., M/s. E-Prarisaraa Pvt. Ltd., M/s. K. G. Nandini Recyclers, M/s. Ash Recyclers, and M/s. New Port Computer Services India Pvt. Ltd., E-R3 Solutions Pvt. Ltd., etc. In the formal sector, E-Prarisaraa has been encouraged by the Central and State Pollution Control Board to get replicated in all major cities in the country [19].

\section{Status of E-waste in Hyderabad}

For some time, Hyderabad has been known as the emerging Silicon capital of India. The annual ewaste generation has been estimated to be 3,263,994 MT from various kind of equipment's such as computers, printers, television and mobile phones. The breakup is as follows: $3111.25 \mathrm{MT}$ from computers, 86.46 MT from printers, 61.0 MT from televisions and 5.284 MT from mobile phones. In 2010, the total e-waste projection for Hyderabad with a population of z74.42 lakh was 98,163 kg. Including 42,869 computers, 53,581 televisions and 1,713 mobile phones. In 2013 , with a projected population of 81.81 lakh, the total e-waste volume is expected to reach 1, 07,886 kg. Including 47,117 computers, 58,890 televisions and 1,881mobile phones. Most of the ewaste collectors and recyclers only do size reduction (shredding) and segregation [20]. M/s. Earth Sense Recycle Pvt. Ltd. and M/s. Ramky E-waste Recycling Facility are two formal recycling units in Andhra Pradesh, where most of the e-waste generated ends up in informal recycling centers. The lack of infrastructure facility to handle large volume of e-waste paves way for the evolving of informal sectors. Formal recycling is yet to take up in a big way, as business is more profitable in the unorganized sector. The unorganized sector has to be given little incentive to manage the e-waste in formal recycling units which involves the responsibility of the government [21-24].

\section{E-waste Global scenario}

As the fastest growing component of municipal waste across the world, it is estimated that more than $50 \mathrm{MT}$ of e-waste is generated globally every year. In other words, these would fill enough containers on a train to go round the world once [25].18 USA discards 30 million computers each year and 100 million phones are disposed of in Europe each year [26]. An estimated 50 million tons of E-waste are produced each year [27,28]. The United States is the world leader in producing electronic waste, tossing away about 3 million tons each year [29].As far as global e-waste management is concerned, Switzerland is the first country to implement the organized e-waste management system in the world. Extended Producer Responsibility (EPR) and Advance Recycling Fee (ARF) are the backbone of e-waste management system in Switzerland and other developed countries Advanced countries like USA, UK, France \&Germany generate 1.5 to 3 million tons of E-Waste annually and are among the largest generators of E-Waste. But these countries also have standardized e-waste management processes in place. Proper E-Waste management, from efficient sourcing and collection right up to extraction and disposal of material, has ensured that this huge pile of junk turns into a lucrative business opportunity. Due to very stringent environmental standards, the cost of collection, preprocessing, recycling and disposal are pretty high. So for every organized recycler in the first world countries, there are quite a few who pose as recyclers and are mere brokers who ship these obsolete items to developing countries like India and China in the pretext of donation or second hand goods. With very ambiguous laws related to environmental protection, India , China and a few African countries have become dumping sites to the first world countries. There are many countries that have already started the „take back" system for electronic products and they also have dedicated laws on e-waste management. In USA, National Electronics Action Plan has been initiated by US Environment Protection Agency to address the various issue related to electronic waste. Two very important frameworks for protecting environment from e-waste have been put forward by European Union i.e., WEEE Directives and Restriction of use of Certain Hazardous Substances (RoHS), which are also implemented by other countries. According to EU directives (2003), it is mandatory for all 27 countries of European Union to recycle their e-waste. Basel Convention is also nice step taken by UNEP to control the international trading of hazardous waste and India is also signatory to this $[\mathbf{3 0}, \mathbf{3 1 , 3 2}$. China already produces about 2.3 million tons (2010 estimate) domestically, second only to the United States [33, 34].

\section{Effect on Human Health}

Since e-waste is a diverse combination of various type of toxic elements, which are capable of creating an irreversible impact to the environment and human health if not handled properly. The health hazards of few toxic elements are given below [35, 36, 37].E-waste is highly complex to handle because of its composition. It is made up of multiple components some of which contain toxic substances that have an adverse impact on human 
health and environment if not handled properly that is if improper recycling and disposal methods are deployed. So there is a need for appropriate technology for handling and disposal of these chemicals. Thus, residents living nearby can intake these hazardous chemicals through different exposure pathways. Since the recycling process is done near residential area, population group which is vulnerable to hazardous chemicals, such as infants and children are alike to be affected a lot regarding their health. In this part, PCDD/Fa, a by-product of e-waste recycling is being reviewed. Lead is a highly toxic metal with no known useful function in the human body of particular concern is the effect of relatively low-level exposure on cognitive and behavioral development in children, including the lowering of IQ [38]. Formal electronic waste recycling facilities use specifically designed equipment to safely remove salvageable materials from obsolete electronics while protecting workers from adverse health effects. However, these centers are very expensive to build and run and are rare in less developed countries. Varying national safety standards can mean that workers at formal or semiformal recycling centers still risk exposure at low doses [39]. Because of the high levels of environmental, food, and water contamination, residents living within a specific distance of e-waste recycling areas are also at risk of environmental exposure, although at lower levels than through occupational exposure $[40,41,42]$. Persistent organic pollutants are a group of lipophilic, bio accumulative substances that are very resistant to breakdown because of long half-lives. Common persistent organic pollutants found in electrical and electronic equipment components include: brominated flame retardants (poly brominated diphenyl ethers), polybrominateddiphenyls, dibrominateddiphenyl ethers, polychlorinated biphenyls, poly chlorinated or poly brominated dioxins and dibenzo furans dioxins, hexabromocyclododecanes, and perfluroalkyls. Persistent organic pollutants released during dismantling, typically from incineration and smelting, include polychlorinated dibenzodioxins, polychlorinated dibenzofurans, and dioxin-like polychlorinated biphenyls. Poly cyclic aromatic hydrocarbons are naturally occurring, hydrophobic substances that are formed during incomplete combustion of coal, gas, oil, meat, tobacco, incense, and wood [43, 44]. These hydrocarbons are formed and released into the environment during the burning of e-waste materials [45].Potentially hazardous chemical elements are also components of electrical and electronic equipment; the most common are lead, cadmium, chromium, mercury, copper, manganese, nickel, arsenic, zinc, iron, and aluminum [46]. Regional intergovernmental organizations, international organizations, national governments, and nongovernmental organizations have actively worked to address the practical application of e-waste regulations and initiatives to prevent negative effects on health from the informal recycling of e-waste. However, the focus of e-waste policies and initiatives is only now beginning to shift from a mainly environmental emphasis to one that includes health. New challenges are emerging, and international conventions such as those in Basel [47] Rotterdam [48] and Stockholm [49] will struggle to effectively address growing domestic E-waste streams in developing countries.

Americium: The radioactive source in smoke alarms. It is known to be carcinogenic.

Mercury: Found in fluorescent tubes, tilt switches (mechanical doorbells, thermostats), and flat screen monitors. Health effects include sensory impairment, dermatitis, memory loss, and muscle weakness. Exposure in-utero causes fetal deficits in motor function, attention and verbal domains. Health effects in animals include death, reduced fertility, and slower growth and development.

Sulphur: Found in lead-acid batteries. Health effects include damages to vital organs such as liver, kidney and heart and also causes eye and throat irritation. When released into the environment, it increases the problem of acid rain.

BFRs: Used as flame retardants in plastics in most of the electronic devices. Health effects include impaired development of the nervous system, thyroid \&liver problems. PBBs were banned from 1973 to 1977. PCBs were banned during the 1980s.

Cadmium: Found in light-sensitive resistors, corrosion-resistant alloys for marine and aviation environments, and nickel-cadmium batteries. The most common form of cadmium is found in Nickel-cadmium rechargeable batteries. These batteries tend to contain between 6 and 18\% cadmium. The sale of Nickel-Cadmium batteries has been banned in the European Union except for medical use. When not properly recycled, it can leach into the soil, harming microorganisms and disrupting the soil ecosystem. The inhalation of cadmium can cause severe damage to the lungs and is also known to cause kidney damage. Cadmium is also associated with deficits in cognition, learning behavior and neuromotor skills in children.

Lead: used as a soldering agent and also used in CRT monitor glass, lead-acid batteries etc., Adverse effects of lead exposure include impaired cognitive function, behavioral disturbances, attention deficits, hyperactivity, conduct problems and lower IQ.

Beryllium oxide: Filler in some thermal interface materials such as thermal grease used on heat sinks for CPUs and power transistors, magnetrons, X-ray-transparent ceramic windows, heat transfer fins in vacuum tubes, and gas lasers.

Hexavalent chromium: A known carcinogen after occupational inhalation exposure. The above health effects show that precautions have to be taken in handling the e-waste to overcome the health hazards [19]. 
Disposal of e-wastes is a particular problem faced in many regions across the globe. Computer wastes that are land filled produces contaminated leachates which eventually pollute the groundwater. Acids and sludge obtained from melting computer chips, if disposed on the ground causes acidification of soil. For example, Guiyu, Hong Kong a thriving area of illegal e-waste recycling is facing acute water shortages due to the contamination of water resources [50].If these electronic items are discarded with other household garbage, the toxics pose a threat to both health and vital components of the ecosystem. In view of the ill-effects of hazardous wastes to both environment and health, several countries exhorted the need for a global agreement to address the problems and challenges posed by hazardous waste. Also, in the late 1980s, a tightening of environmental regulations in industrialized countries led to a dramatic rise in the cost of hazardous waste disposal. Searching for cheaper ways to get rid of the wastes, "toxic traders" began shipping hazardous waste to developing countries. International outrage following these irresponsible activities led to the drafting and adoption of strategic plans and regulations at the Basel Convention. The Convention secretariat, in Geneva, Switzerland, facilitates and implementation of the convention and related agreements. It also provides assistance and guidelines on legal and technical issues, gathers statistical data, and conducts training on the proper management of hazardous waste $[\mathbf{5 1}, \mathbf{5 2}]$.

\section{Discussion}

To the best of our knowledge, Electronic equipment and therefore E-waste are everywhere in our society. They are characterized by a complex chemical composition and difficulty in quantifying their flows at a local and international level. The pollution caused by their irregular management substantially degraded the environment mostly in poorer countries, receiving them for recycling and recovery of their valuable metals. As for the consequences on ecosystems, human health and environmental restoration of areas burdened by certain polluters generated by e-waste (e.g. $\mathrm{Li}, \mathrm{Sb}, \mathrm{Hg}$ ), there are no sufficiently documented scientific studies. We identified 23 studies that examined associations between exposure to e-waste and health and learning outcomes, but no studies in which an association between exposure to e-waste and violence or criminal behavior was investigated We included violence and criminal behavior as potential outcomes because of proposed associations between exposure to heavy metals, aggression, and violent crime [53, 54]. An effective take-back program providing incentives for producers to design products that are less wasteful, contain fewer toxic components, and are easier to disassemble, reuse, and recycle may help in reducing the wastes. This is due to disposal of recycling wastes such as acids, sludges etc. in rivers. Now water is being transported from faraway towns to cater to the demands of the population. Incineration of e-wastes can emit toxic fumes and gases, thereby polluting the surrounding air. Improperly monitored landfills can cause environmental hazards. Mercury will leach when certain electronic devices, such as circuit breakers are destroyed. The same is true for polychlorinated biphenyls (PCBs) from condensers [55]. When brominates flame retardant plastic or cadmium containing plastics are land filled, both polybrominateddiphenyl ethers (PBDE) and cadmium may leach into the soil and groundwater. It has been found that significant amounts of lead ion are dissolved from broken lead containing glass, such as the cone glass of cathode ray tubes, gets mixed with acid waters and are a common occurrence in landfills. The toxic fall-out from open air burning affects both the local environment and broader global air currents, depositing highly toxic byproducts in many places throughout the world [56, 57].

\section{Conclusion}

The best available practices from different countries can be adopted to have a standardized E-waste management process in place. The proper E-waste management will help efficient sourcing and collection right upto extraction and disposal of material, ensure that this huge pile up of E-waste will turn into lucrative products and business opportunity. This E-waste management should cover need all round efforts ranging from technological improvement, institutional arrangement, operational plan, protective protocols for workers engaged in such units and at last education of the people at large by introducing it as part of curriculum in higher secondary education. The major types of pollutants which are included in each type of appliance can be categorized broadly as hazardous wastes (heavy metals such as $\mathrm{Cu}, \mathrm{Ni}, \mathrm{Pb}, \mathrm{Ag}, \mathrm{Au}, \mathrm{Cr}$ etc., persistent organic pollutants, and polychlorinated biphenyls ) non- hazardous wastes (ferrous metal such as Iron and Steel, nonferrous metals such as Copper and Aluminum, plastic, rubber, glass etc.). Improper handling of E-waste can cause harm to the environment and human health because of its toxic components. Most of the E-waste finds its way to the unorganized sector with profit as the prime motivating factor, hence technical improvements of informal recycling processes coupled with proper training in handling waste electrical and electronic equipment's has to be offered to the local industry and community so to obtain better environmental performance without sacrificing the economic and social benefits.Most waste is inherently dangerous. It can degrade to produce leachate, which may contaminate ground water, and create landfill gas, which is explosive. In addition, because of the dangers associated with landfill sites, there are now very strict requirements on the construction, operation and aftercare of such sites. Most planning authorities want a worked out quarry to be 
used for landscaping rather than a landfill site which no one wants in their „,back yard". Product design must be employed to help to minimize not only the nature and amount of waste, but also to maximize end-of-life recycling. Manufacturers, retailers, users, and disposers should share responsibility for reducing the environmental impacts of products. Adopt product stewardship approach i.e. a product-centered approach should be adopted to preserve and protect environment [58].Electronic goods Manufacturing Companies must be legally ensured to mention the disposal methods of their product in their user manual. As E-wastes are the known major source of heavy metals, hazardous chemicals and carcinogens, certainly diseases related to skin, respiratory, intestinal, immune, and endocrine and nervous systems including cancers can be prevented by proper management and disposal of E-waste. With a view to bridge the digital divide, there is exponential growth in the use of Electrical and electronic equipment (EEE) and so there is alarming effect on environment and human health when the ICT wastes are not disposed of scientifically. There is an emergent need to implement the existing policies and guidelines in line with the international standards and practices for an healthy E-waste management system.

\section{References}

[1]. Radha G. (2002). A Study of the Performance of the Indian IT Sector' at www.nautilus.org accessed on 21st June 2005

[2]. DIT (2003). Environmental management for Information Technology industry in India, Department of Information Technology, Government of India, pp.122-124.

[3]. Status Report on e-Waste Management In Sri Lanka. CentralEnvironmental Authority, August 2010.

[4]. Bertram, M., Graedel, T.E., Rechberger, H., Spatari, S., 2002. The contemporary European copper cycle: waste management subsystem. Ecological Economics 42 (1-2), 43-57.

[5]. Brigden, K., Labunska, I., Santillo, D., Johnston, P., 2008. Chemical contamination at e-waste recycling and disposal sites in Accra and Korforidua, Ghana.Greenpeace Research Laboratories Technical Note. Greenpeace International, Amsterdam, TheNetherlands. <http://www.greenpeace.org/international/press/reports/chemical contamination-at-e-wa>.

[6]. Williams, E., 2005. International activities on E-waste and guidelines for future work. In: Proceedings of the Third Workshop on Material Cycles and Waste Management in Asia, December, 2004, Tsukuba, Japan.

[7]. Hazardous wastes (management and handling) rules, 1989/2000/2002

[8]. Moef guidelines for management and handling of hazardous wastes, 1991

[9]. Basel Action uploaded on (2013) Exporting Harm: The High-Tech Trashing of Asia [video file] Retrieved from http://www.youtube.com/watch?v=yDSWGV3jGek

[10]. Guidelines for safe road transport of hazardous chemicals, 1995

[11]. Schluep, M. et al. 2009. Recycling: From e-waste to resources, Sustainable Innovation and Technology Transfer Industrial Sector Studies (Nairobi and Bonn, UNEP and STeP).Available:http://www.unep.org/PDF/PressReleases/EWaste_publication_scren FINALVERSION-sml.pdf [8 Dec. 2011].

[12]. G. Gaidajis, K. Angelakoglou and D. Aktsoglou / Journal of Engineering Science and Technology Review 3 (1) (2010) 193-199

[13]. Text of the Basel Convention on the Control of Transboundary Movements of Hazardous Wastes and Their Disposal, UNEP, Geneva, Switzerland, p.6, http://www.basel.int/text/

[14]. RakeshJohri ,"E-Waste Implications,regulations and management in India and current global best pratices,"The energy and Resources Institute 2008

[15]. CII, "E-waste management," Green Business Opportunities, vol. 12, no. 1, Confederation of Indian Industry, Delhi 2006.

[16]. B R Babu; A K Parande; C A Basha, Waste Manage. Res., 2007, 25, 307-318.

[17]. A Agarwal; A Singhmar; M Kulshrestha; A K Mittal, Res. Conservation and Recycling, 2005, 44 (1), 73-90.

[18]. Junaidah Ahmad Kalana, International J. of Environmental Sc., 2010, 1(2),132-144.

[19]. J. Chem. Pharm. Res., 2015, 7(3):232-238

[20]. G Gaidajis; K Angelakoglou; D Aktsoglou, J. of Engineering Science and Tech.-Review, 2010, 3(1), $193-199$.

[21]. R B Balakrishnan; K P Anand; A B Chiya, J. of Waste Manage. Res., 2007, 25, 307-317.

[22]. M H Wong; Wu; S C Deng; Yu W J; X Z Luo; Q Leung, Env. Pollutison, 2007, 149(2), 131-140.

[23]. E Yoheeswaran, Global Research Analysis, 2013, 2(4), 105-112

[24]. S Chatterjee; K Kumar, International Journal of Physical Sciences. 2009, 4(13), 893-905.

[25]. Schwarzer S., A.D. Bono et al, 'E-waste, the hidden side of IT equipment's manufacturing and use', Environment Alert Bulletin (UNEP Early Warning on Emerging Environmental Threats), No. 5, 2005.

[26]. US Environmental Protection Agency. [Online]. Available: http://www.epa.gov/epawaste/conserve/materials/ecycling/manage.ht m. Retrieved 2012-03-13.

[27]. United Nations News Service 2010 United Nations-DPI/NMD - UN News Service Section. [Online]. Available: http://www.un.org/apps/news/story.asp? NewsID=33845.

[28]. Outdated Computers. [Online]. Available: http://green.tmcnet.com/topics/green/articles/37567-cash-laptops-offe rs-green-solutionbroken-outdated-computers.htm.

[29]. C. Terence. America Ships Electronic Waste Overseas [Online]. Available: http:/ /biz.yahoo. com/ap /071118/ exporting_e_ waste.html?.v=3

[30]. Vinod Kumar Research Scholar, Department of Management Studies, Indian Institute of Technology, Roorkee, Uttarakhand (India)-247667 [E-mail: vinodmehta8383@gmail.com, +91-9639300292],"Sustainability and E-waste Management Scenario in Indiaby"

[31]. RakeshJohri ,'E-Waste Implications,regulations and management in India and current global best pratices,'The energy and Resources Institute 2008

[32]. Khetriwal, D. S., Kraeuchi, P., \&Schwaninger, M.(2005). A comparison of electronic waste recycling in Switzerland and in India. Journal ofEnvironmental Impact Assessment Review, 25,492-504.

[33]. R. Kahhat and E Williams, "Product or Waste? Importation and End-of-Life Processing of Computers in Peru," Center for Earth Systems Engineering and Management, Arizona State University, published Environmental Science and Technology June 2009.

[34]. CBC News. [Online]. Available: http://www.cbc.ca/mrl3/23745/thenational/archive/ewaste-102208.w mv.

[35]. J Sergio; M Tohru, J. of Material Cycles Waste Mgmt., 2005, 7, 24-32

[36]. P MonomaiviBool, J. of Resources Conservation and Recycling. 53(3), 2009, 1366-1444.

DOI: $10.9790 / 2402-10090198104 \quad$ www.iosrjournals.org


[37]. J Ammons; B Sarah, www.lionhrtpub.com. 2003

[38]. ATSDR (2003) Toxicological profiles on CD-ROM. Agency for Toxic Substances and Disease Registry. U.S. Public Health Service.

[39]. Schluep M, Hagelüken C, Meskers C, et al. Market potential of innovative e-waste recycling technologies in developing countries. R'09 World Congress; Davos, Switzerland; Sept 14-19, 2009. 1-8.

[40]. Wong CS, Duzgoren-Aydin NS, Aydin A, Wong MH. Evidence of excessive releases of metals from primitive e-waste processing in Guiyu, China. Environ Pollut2007; 148: 62-72.

[41]. Yu XZ, Gao Y, Wu SC, Zhang HB, Cheung KC, Wong MH. Distribution of polycyclic aromatic hydrocarbons in soils at Guiyu area of China, affected by recycling of electronic waste using primitive technologies. Chemosphere 2006; 65: 1500-09.

[42]. Fu J, Zhou Q, Liu J, et al. High levels of heavy metals in rice (Oryza sativa L.) from a typical E-waste recycling area in southeast China and its potential risk to human health. Chemosphere 2008; 71: 1269-75.

[43]. Agency for Toxic Substances and Disease Registry (ATSDR). Toxicological profi le for polycyclic aromatic hydrocarbons (PAHs). Atlanta, GA: US Department of Health and Human Services, Public Health Service, 1995.

[44]. Liu G, Niu Z, Van Niekerk D, Xue J, Zheng L. Polycyclic aromatic hydrocarbons (PAHs) from coal combustion: emissions, analysis, and toxicology. Rev Environ ContamToxicol2008; 192: 1-28.

[45]. Wang Y, Tian Z, Zhu H, et al. Polycyclic aromatic hydrocarbons (PAHs) in soils and vegetation near an e-waste recycling site in South China: concentration, distribution, source, and risk assessment. Sci Total Environ 2012; 439: 187-93.

[46]. Jinhui L, Huabo D, Pixing S. Heavy metal contamination of surface soil in electronic waste dismantling area: site investigation and source-apportionment analysis. Waste Manag Res 2011; 29: 727-38.

[47]. United Nations Environment Programme (UNEP). Basel convention on the control of transboundary movements of hazardous waste and their disposal. 1989. http://www.basel.int/ Portals/4/Basel\%20Convention/docs/text/BaselConventionText-e. pdf (accessed Oct 17, 2013)

[48]. United Nations Environment Programme (UNEP). Rotterdam convention on the prior informed consent procedure for certain hazardous chemicals and pesticides in international trade. 1998. http://www.unido.org/fi leadmin/ user_ media/ Services/Environmental_Management/GUDDIS/Legal_Frameworks/rotterdam_convention.pdf (accessed Oct 17, 2013).

[49]. United Nations Environment Programme (UNEP). Stockholm convention on persistent organic pollutants. 2001. http://www.pops. int/documents/convtext/convtext en.pdf (accessed Oct 17, 2013).

[50]. L. Nageswara Rao /Int.J. ChemTech Res.2014,6(2), pp 1343-1353.

[51]. Freeman M. H., 1989, Standard Handbook of Hazardous Waste Treatment and Disposal, McGraw-HillCompany, USA.

[52]. L. M. Hilty, 2005 "Electronic waste_-an emerging risk?" Environmental Impact Assessment Review, Vol. 25, 431-435.

[53]. Carpenter DO, Nevin R. Environmental causes of violence. PhysiolBehav2010; 99: 260-68.

[54]. Needleman HL, McFarland C, Ness RB, Fienberg SE, Tobin MJ. Bone lead levels in adjudicated delinquents. A case control study. NeurotoxicolTeratol2002; 24: 711-17.

[55]. UNEP, 2010, 'E-waste Volume-I (Inventory Assessment Manual)',Vol.1,145-162.

[56]. Sivakumar.T, 2011, “Global Challenges in E-waste Management: Indian Scenario”, International Journal of Advanced Engineering Technology, Vol.2, 10-15.

[57]. RamachandraT.V,Saira V. K.,2004, "Environmentally sound options for waste management", Envis. Journal of Human Settlements.

[58]. Vijay et al., International Journal of Advanced Research in Computer Science and Software Engineering 4(2), February - 2014, pp. 442-447 